\title{
Management of Reputation Risks at the Agricultural Enterprises of Eastern Europe as a Component of Increasing Their Competitiveness
}

\author{
Oleg V. Zakharchenko ${ }^{1}$, Alina R. Eremina ${ }^{2}$, Denis S. Ushakov ${ }^{3,}$, Oleh M. Odintsov $^{4}$, \\ Serhii M. Mylnichenko ${ }^{5}$
}

${ }^{1}$ Department of Management and Marketing, Institute of Business and Information Technology, Odessa State Academy of Civil Engineering and Architecture, Odessa, Ukraine

${ }^{2}$ Office of Doctoral Studies, Major "Social Sciences", Federal State Autonomous Educational Institution for Higher Education National Research University Higher School of Economics, Moscow, Russia

${ }^{3}$ Suan Sunandha Rajabhat University, Bangkok, Thailand

${ }^{4}$ Economic and Business Department, Cherkasy State Technological University, Cherkasy, Ukraine

${ }^{5}$ Department of Business Administration and Management, Cherkasy State Technological University, Cherkasy, Ukraine

\begin{abstract}
We note a significant role of the agricultural sector in the development of economic systems in a significant number of post-Soviet countries of Eastern Europe. However, Eastern European agricultural enterprises have significant problems in ensuring and managing their competitiveness, where reputation and the risks associated with it are of key importance. Novelty. The scientific novelty of the research paper is the developed algorithm of reputation risk management, which is based on the author's methodology of their evaluation and takes into account the peculiarities of such management in agricultural enterprises from the post-Soviet countries of Eastern Europe. To achieve the goal and test the hypotheses put forward in the research paper, a set of general, specific and technical methods were used at the empirical and theoretical levels, such as: abstraction method; expert method; methods of analysis and synthesis; comparison; deduction; induction; methods of systematization, grouping and logical generalization. The research methodology is based on systemic and functional, historical and systemic approaches in identifying and resolving the range of problems of reputation risk management within the framework of improving the competitiveness management of agro-industrial enterprises from the post-Soviet countries of Eastern Europe. For the purpose of the study, data were collected and an empirical analysis was conducted concerning the eleven Eastern European countries that were part of the Soviet Union for 1991-2018 regarding analysis of the dynamics of agricultural production and its share in GDP according to statistics taken from the KNOEMA databases. Policy considerations: the agricultural sector of the economy plays an increasing role in the economic systems of some post-Soviet countries of Eastern Europe, serving as the basis for their sustainable development; agricultural producers from the post-Soviet space of Eastern Europe have problems with ensuring competitiveness in national, international and world markets; reputation risk plays a significant role in ensuring and improving the competitiveness management of agricultural enterprises from post-Soviet countries of Eastern Europe; the formation of an effective reputation risk management algorithm is a key element in ensuring and improving the competitiveness management of Eastern European agricultural producers.
\end{abstract}

Keywords: Agricultural enterprises, Reputation risk assessment, Reputation, Competitiveness management, Reputation risk management.

\section{INTRODUCTION}

A gradual transition of the most developed countries of the world from the concept of building an industrial to a post-industrial economy, based on the active development of its "tertiary" sector (service sector) transforms the world economic system and influences the development of "primary" (agricultural production) and "secondary" (industrial production) sectors at all levels of such a system (local, regional, national, international, global). At the same time, we note the growing role of agricultural production in a number of

*Address correspondence to this author at the Suan Sunandha Rajabhat University, Bangkok, Thailand; Tel: +66814393123; Fax: +6621601010;

E-mail: Denis.us@ssru.ac.th developing countries, which include the post-Soviet countries of Eastern Europe. Since independence, these countries have undergone a difficult period of reindustrialization, leading to the gradual loss of their industrial potential and the growing role and importance of agriculture for their sustainable development (Röthig, 2017).

The agricultural sector, given its higher resilience to crisis in the global, international and national economies (FAO, 2018), as well as lower competition in a large number of segments due to high growth in food demand (FAO, 2019), is increasingly important to ensure development of national economic systems of post-Soviet countries (Kimhi and Lerman, 2015). At the same time, as agricultural markets have emerged, 
agribusinesses from the post-Soviet countries of Eastern Europe are increasingly focusing on ensuring and maintaining their competitiveness in local, regional, national, international and global agricultural markets, as well as improving the efficiency of managing their competitiveness (Gusakov and Shpak, 2018; Shvets and Butenko, 2017; Trubilin, Sidorenko and Mikhailushkin, 2016).

We note considerable scientific interest of both scholars from the post-Soviet countries of Eastern Europe and scholars from other countries to the problems of development of the agricultural sector of the economy (Chang and McAleer, 2014; Csaki and Nucifora, 2006; Hvid, 2013; llina, Miloradov and Kovaltchuk, 2019; Khasanov and Ksenofontov, 2018; Kuipers, Rozstalnyy and Keane, 2014; Petrick and Weingarten, 2004) and ensuring the competitiveness of agricultural producers (Chryniewicz, Kyryliuk and Wojtaszek, 2016; Kovaltchuk, Blinova and Miloradov, 2017; Kovaltchuk et al., 2016; Maslova et al., 2019; Patyka, 2018) of these states. At the same time, we emphasize the need for further transformation of agricultural producers in the post-Soviet countries of Eastern Europe in the context of increasing their competitiveness and taking into account the peculiarities of their financial and economic activity, as well as the key risks of its implementation, where one of the main ones is the reputational risk.

The range of problems of the study of factors and risks affecting the competitiveness of agricultural producers are one of the most relevant in scientific economic research (Bečvářová, 2008; Gunjal, 2016; Matyja, 2016; Sachitra and Chong, 2016). At the same time, we note that most scholars do not consider reputation risk as a key risk for agricultural producers' competitiveness, considering it important for industry and services (Giorgino and Monda, 2014; Heidinger and Gatzert, 2017; Pagach and Warr, 2009).

Given that intangible assets account for $70-80 \%$ of market value of a business entity, including an agricultural producer, where a significant number of these assets are determined by reputation risks (Eccles, Newquist and Schatz, 2007), reputation risk management is a key aspect of ensuring its competitiveness and sustainable development. The importance of reputation risks and managing them in ensuring and enhancing competitiveness was also confirmed by the Global Risk Management Survey conducted by AON (2019), where reputation risks were identified as one of the most dangerous for business.
Thus, a critical study of scientific research allows identifying the following problems:

insufficient attention to and management of reputational risks within the framework of ensuring and improving the efficiency of managing the competitiveness of agricultural producers;

- the need to find new ways to increase the efficiency of managing the competitiveness of agricultural enterprises from the post-Soviet countries of Eastern Europe within the framework of continuing the processes of reindustrialization and increasing the weight of the "primary" sector in the economic systems of these countries.

The identified problems allowed formulating the objective of the research, namely: to develop ways of improving the competitiveness management of agricultural enterprises in Eastern Europe based on the introduction of reputation risk management.

For this purpose, it is important to confirm or refute a number of hypotheses, namely:

the agricultural sector of the economy is playing an increasing role in the economic systems of the post-Soviet countries of Eastern Europe, serving as the basis for their sustainable development;

agricultural producers from the post-Soviet space of Eastern Europe have a high level and effectively manage the competitiveness in national, international and world markets;

within the framework of ensuring and improving the efficiency of managing the competitiveness of agricultural enterprises from post-Soviet countries of Eastern Europe, reputational risk plays a significant role;

the formation of an effective reputation risk management algorithm is a key element in ensuring and improving the competitiveness management of Eastern European agricultural producers.

\section{MATERIALS AND METHODS}

Within the framework of scientific research, a set of general and specific methods at the empirical and theoretical levels was used to achieve the objertive 
and test the hypotheses put forward in the research paper, such as: abstraction method for identification and description of types of agricultural producers in the post-Soviet countries of Eastern Europe; methods of analysis and synthesis to identify trends and problems in the development of the agricultural sector of the economy in Eastern European countries; comparison to describe the factors influencing the competitiveness of agricultural enterprises in the post-Soviet countries of Eastern Europe; deduction to study the impact of reputation (reputation risks) on the relationship of Eastern European agricultural enterprises with their main counterparty groups; induction for forming the algorithm of reputation risk management at agribusinesses from the post-Soviet countries of Eastern Europe; methods of systematization, grouping and logical generalization for systematization of information, drawing conclusions and making scientific proposals of the research paper.

The research methodology is based on systemic and functional, historical and systemic approaches in identifying and resolving reputation risk management within the framework of improving the competitiveness management of agro-industrial enterprises from the post-Soviet countries of Eastern Europe. At the same time, the systemic and functional approach allows identifying the place of reputation risks in managing the competitiveness of Eastern European agricultural producers. The historical approach has been used to work out a chronology of the development of the agricultural sector of the economy of the post-Soviet countries of Eastern Europe, as well as to evaluate its development over the period from 1991 to 2018. The systemic approach allows considering agricultural enterprises, their competitiveness and reputation as components of the economic systems of post-Soviet countries of Eastern Europe.

In this research paper, reputation and its risks are presented as one of the key elements of ensuring competitiveness, as well as improving its management efficiency in Eastern European agricultural producers from the post-Soviet economic space. The research is also based on the assumption that agricultural enterprises from the post-Soviet countries of Eastern Europe need to develop and implement reputation risk management in the context of ensuring their competitiveness in local, regional, national, international and global agricultural markets. At the same time, the key importance within the management should be attributed to the identification and

Table 1: Chronology of Development of the Agricultural Sector of the Economy of the Post-Soviet Countries of Eastern Europe

\begin{tabular}{|c|c|}
\hline Stages (years) & Description of the stage \\
\hline 1991-1996 & $\begin{array}{l}\text { The prevalence of ineffective "Soviet" forms of the organization of production (collective farms and state farms), as } \\
\text { well as the increasing role of private plots and small land plots (up to } 6 \text { hectares of land) of urban population ("summer } \\
\text { residences"). Barter growth and critical shortage of resources for agricultural producers. Low export volumes due to } \\
\text { increased imports of agricultural products. The sharp growth of the "shadow" market. Lack of state support. }\end{array}$ \\
\hline $1996-2000$ & $\begin{array}{l}\text { Active transformation of agricultural producers of the old formation into new business forms. The emergence of farms. } \\
\text { Increase in the volume and role of private plots and small land plots (up to } 6 \text { hundred square metres of land) of urban } \\
\text { population. Setting up new supply chains and product sales. Export growth. A high share of the "shadow market". } \\
\text { Chaotic attempts of support from state institutions. }\end{array}$ \\
\hline $2000-2008$ & $\begin{array}{l}\text { Transition to new forms of business organization. Increase in the number of farms. The significant role of private plots } \\
\text { and a sharp decrease in the number and role of summer houses. Significant growth in exports. The emergence of } \\
\text { large agricultural producers and agroholdings. The gradual entry of multinationals into the market. Decrease in the } \\
\text { share of the "shadow market". Increase in the volume and direction of state support as well as support from } \\
\text { international financial institutions. }\end{array}$ \\
\hline $2008-2010$ & $\begin{array}{l}\text { Increasing role of large agricultural producers and agricultural holdings. Increase in exports and its share in total } \\
\text { exports of countries. Increase in the share of the "shadow market". The volume of state support has been determined } \\
\text { in the context of increased support for agricultural production from other sources. Increasing reputation risks. }\end{array}$ \\
\hline $2010-2014$ & $\begin{array}{l}\text { Defining the agricultural sector as a key sector of national economies and reducing disparity in attracting resources to } \\
\text { industry. Increase in investment, innovation and export supply. Implementation of the latest mechanisms of production } \\
\text { management and automation. Reputation risk management issues. Increasing role of multinational corporations in the } \\
\text { agricultural markets of the countries. }\end{array}$ \\
\hline $2014-\ldots$ & $\begin{array}{l}\text { A critical increase in the role of the agricultural sector in several countries and an increase in its share in exports. The } \\
\text { predominance of large agricultural producers and agricultural holdings, including those with foreign capital. Enhancing } \\
\text { the development of farms and cooperatives. Increased government and other types of support. Active replacement of } \\
\text { fixed assets. Introduction of IT technologies. Increase in investment and innovation. Struggle for manpower with the } \\
\text { "secondary" and "tertiary" sectors of the economy. Reputation risk management issues. }\end{array}$ \\
\hline
\end{tabular}


assessment of the reputation risks inherent in Eastern European agricultural enterprises.

\section{RESULTS}

3.1. Assessment of the Development of the "Primary" Sector in the Economies of the PostSoviet Countries of Eastern Europe

The agricultural sector of the economies of the Eastern European countries that were part of the Soviet Union has gone a long way in transforming and reforming since the independence of the countries and the beginning of building economic systems of market type, which allows distinguishing and describing a number of historical stages of its development (Table 1).

Considering the above chronology (see Table 1), we note that the agricultural sector of the economies of Eastern European countries that were part of the Soviet Union has undergone a significant transformation, becoming increasingly important for the development and maintenance of national and economic security of these countries. At the same time, with the growing role of agricultural producers in the economic systems of the post-Soviet countries of Eastern Europe, an increasing challenge is the management of reputation risks, which is one of the key constraints on the development of agriculture in these countries and the entire national economy in these countries.

It should be noted that, as part of the study, a further evaluation of agricultural development will be carried out in relation to post-Soviet countries of Eastern Europe, such as Lithuania, Latvia, Estonia, Belarus, Ukraine, Moldova, Russia, Kazakhstan, Georgia, Armenia, Azerbaijan. At the same time, we consider it advisable to carry out the study from 1991 to 2018 to reveal the whole period of transformation of the "primary" sector of the above countries since independence.

It should be emphasized that since 1991 all the Eastern European countries that were part of the Soviet Union have gone through a difficult path of development of national economic systems, which has affected the development of their agriculture and needs some clarification:

Lithuania, Latvia, Estonia, having a high level of agricultural producers and a high rate of reform of national economies, since 2004 (the year of accession to the European Union) have integrated their own economic systems and agricultural production into the economic space of the European Union;

- $\quad$ Moldova and especially Ukraine have taken the path of active development of agricultural production, constantly changing the vectors of this development;

- Russia, Kazakhstan, Azerbaijan, counting on extraction and export of energy resources, transformed agricultural production based on the peculiarities of development of their economic systems;

- $\quad$ Belarus tried to develop agriculture on the basis of a slight transformation of the Soviet system of agriculture with the decisive role of the state in it;

- Georgia and Armenia are actively focusing on niche agricultural products, taking into account national features of agricultural production;

Russia, Kazakhstan and especially Ukraine are on the path of development of large agricultural producers and agroholdings, which generate large volumes of agricultural land in their ownership and are oriented mainly towards export of crop products.

Special mention should be made regarding the choice of Kazakhstan for the study, as this country mainly belongs to Asia not to Eastern Europe. Kazakhstan was chosen because part of its territory is in Eastern Europe and this country has significant equal aspects in agricultural development with other post-Soviet countries of Eastern Europe, especially Russia and Ukraine, while simultaneously competing with them in certain agricultural markets, such as grain markets (FAO, 2018; 2019).

In the context of assessing the development of agricultural production in the countries selected for the study, it is important to analyze the dynamics of agriculture and its share in GDP over the relevant period of time (Table 2). At the same time, we will rely on the above chronology in determining the timeframe of the study (see Table 1).

Based on the results of the analysis, we can draw the following conclusions:

Significant increase in agricultural production during the study period. Thus, with the exception of Lithuania, Latvia and Estonia, in other post- 
Table 2: Analysis of the Dynamics of Agricultural Production and its Share in the GDP of Post-Soviet Countries of Eastern Europe for 1991-2018

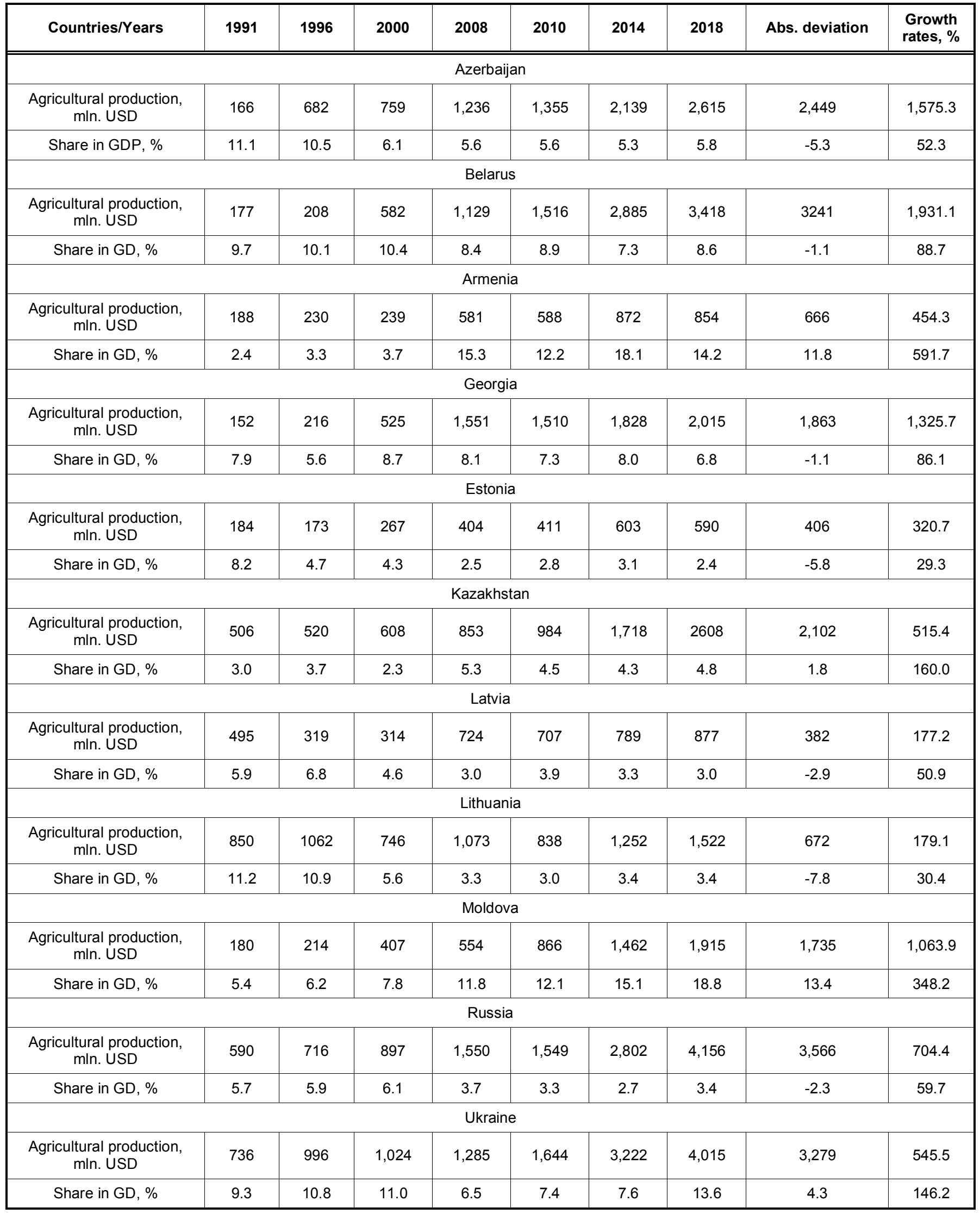

*- Developed by the author based on KNOEMA (2019). 
Table 3: Types of Agricultural Producers in the Post-Soviet Countries of Eastern Europe

\begin{tabular}{|c|c|}
\hline $\begin{array}{l}\text { Type of agricultural } \\
\text { producer }\end{array}$ & Description of the agricultural producer \\
\hline $\begin{array}{l}\text { Small unregistered } \\
\text { manufacturers (private } \\
\text { plots, summer residences) }\end{array}$ & $\begin{array}{l}\text { A considerable amount of the produced products goes for own consumption. They work only in the "shadow } \\
\text { economy". They use the work of the owner and his family members. They do not use modern equipment and } \\
\text { innovations, have scarce resources. }\end{array}$ \\
\hline Small unregistered farms & $\begin{array}{l}\text { They work mainly in the "shadow economy". They use the work of the owner and his family members, as well } \\
\text { as hire workers during the season. They do not use modern equipment and innovations, have scarce } \\
\text { resources. They are focused on local agricultural markets. }\end{array}$ \\
\hline Small farms & $\begin{array}{l}\text { They have a high share of income from the "shadow economy". They use the work of the owner and his family } \\
\text { members, as well as hire workers during in the season. They do not use modern equipment and innovations, } \\
\text { they have problems with attracting resources, especially financial ones. They are focused on local and } \\
\text { regional agricultural markets. }\end{array}$ \\
\hline $\begin{array}{l}\text { Medium-sized agricultural } \\
\text { producers }\end{array}$ & $\begin{array}{l}\text { They have a high share of income from the "shadow economy". They use the work of the owner and his } \\
\text { family members, as well as hired workers. They do not make enough use of modern equipment and } \\
\text { innovations, have problems with attracting resources, especially financial. They are focused on local, regional } \\
\text { and national agricultural markets. }\end{array}$ \\
\hline Agroholdings & $\begin{array}{l}\text { They have a certain share of income from the "shadow economy". They use the work of hired workers. They } \\
\text { do not make enough use of innovations and information technologies, they have certain problems with } \\
\text { attracting resources. They are focused on national, international and global agricultural markets. }\end{array}$ \\
\hline
\end{tabular}

Source: developed by the author on base Czyżewski (2015), Gusakov (2018), Khasanov (2018) and Maslova (2019).

Soviet countries of Eastern Europe agricultural production growth rates ranged from $515.4 \%$ in Kazakhstan and $545.5 \%$ in Ukraine to $1931.1 \%$ in Belarus and $1,575.3 \%$ in Azerbaijan. Such high growth rates were caused by both the increase in agricultural production in the countries selected for the study, and the low base of comparison due to the significant devaluation of national currencies in 1991-1996, as well as by inflationary processes in the world and national economies.

(2) Too high share of the "primary" sector in a large number of economies of the countries selected for the study, with the exception of two categories of countries, namely, Lithuania, Latvia, Estonia, where the share of agriculture in the GDP of the countries began to decline significantly with the accession to the European Union, which is due to the implementation of the modern concept of building a post-industrial economy in these countries; Azerbaijan, Kazakhstan and the Russian Federation, where the share of agricultural production is small against the background of the orientation of these countries to the extraction of energy resources.

(3) Significant or decisive role of the agricultural sector in the economic development of countries with the exception of only Lithuania, Latvia and Estonia, where the role of agriculture in the economic system of the state can be determined as average.

(4) Increase in the role and share of agricultural production in the economic system of countries in times of crisis or development of the world economy (with the exception of Lithuania, Latvia and Estonia), which is associated with the low competitiveness of economies selected for the study, as well as some of their industries and producers, and greater resilience to agricultural crises (FAO, 2018).

In exploring the development of agricultural production in the post-Soviet countries of Eastern Europe, particular attention should be paid to the types of agricultural producers that have historically emerged in these countries and which differ from those producers in economically developed countries (Table $\mathbf{3}$ ).

We note that in the Eastern European countries that were part of the Soviet Union, the agricultural sector is largely "in the shadow", as well as under the influence of poor competition from small unregistered producers of agricultural products that impede the development of small and medium-sized farming. However, both scholars from the post-Soviet countries of Eastern Europe and scholars from other countries (Gusakov 
and Shpak, 2018; Kimhi and Lerman, 2015; Patyka, 2018; Röthig, 2017; Trubilin, et al., 2016) point to a large number of modern problems that hinder the effective development of agricultural production in the countries selected for research, where the following problems are key:

- low competitiveness, especially in the international and world markets, as well as of agricultural processing products;

- reputation problems in relationships with counterparties, competitors, state and local government institutions, as well as the rural community;

- attraction of cheap credit or investment resources in the medium and long term;

- development of innovations, including the management of enterprises and introduction of information technologies in the production and economic activity of agricultural producers.

In view of the above, we consider it appropriate to investigate in greater detail the problems of ensuring and improving the efficiency of managing the competitiveness of agricultural producers from the post-Soviet countries of Eastern Europe.

\subsection{Issues of Ensuring and Increasing the Efficiency of Managing the Competitiveness of Eastern European Agricultural Enterprises}

Competitiveness is one of the key goals for the sustainable development of agricultural producers (Matyja, 2016). At the same time, ensuring, maintaining and enhancing it for agricultural producers has significant differences from industrial and service businesses because of the significant identity of goods offered in markets, as well as protectionist measures in markets in many countries (Sachitra and Chong, 2016). At the same time, agricultural enterprises from developing countries, including those from the postSoviet countries of Eastern Europe, have significant problems in ensuring their competitiveness (Röthig, 2017).

We emphasize that the basic element that is the focus of research of scholars, government institutions and economists-practitioners regarding the competitiveness (competitiveness management) of agricultural producers, including from developing countries, is the identification of factors (risks) to ensure an appropriate competitive position of a business entity in the market.

The USDA (2019), in its own study, focuses on five key risks that reduce the competitiveness of agricultural enterprises, namely: production, price, financial, institutional, personnel training.

Esterhuizen (2006) divides factors that affect the competitiveness (competitiveness management) of agricultural producers into those that restrict it (prices, political system, competence of government officials) and enhance it (intensity of competition in local markets, unskilled labour force, development of high quality agricultural production).

Bečvářová (2008) focuses on the factors of competitiveness (competitiveness management) of agricultural enterprises from the point of view of marketing and distinguishes the following: set of relations with counterparties (architecture of relations); reputation; innovative potential; strategic assets.

Czyżewski and Smędzik-Ambroży (2015), in their study of the "primary" sector of Poland's economic system, focus on such factors as ensuring the competitiveness of agricultural producers, such as labour productivity and assets, as well as performance indicators.

Matyja (2016), based on correlation analysis, identifies three groups of factors affecting the competitiveness (competitiveness management) of agricultural enterprises: resource (personnel, size and quality of agricultural land, assets); non-material (management competencies, technological resources, etc.); external (natural conditions, legal field, etc.).

Sachitra and Chong (2016) distinguish five major factors for ensuring (managing) the competitiveness of agricultural producers, which include: enterprise size; capital; collective actions; state support; ecology.

A brief critical assessment of approaches to determining the competitiveness of agro-industrial enterprises indicates that there is a considerable scientific debate, as well as a shift in emphasis in ensuring (managing) the competitiveness of agricultural producers toward intangible assets, including reputation risk against the background of well-known factors, such as resources and state support.

In this context, we consider it appropriate to identify the key factors affecting the competitiveness (competitiveness management) of agricultural 
Table 4: Assessment of the Factors of Influence on the Competitiveness (Competitiveness Management) of Agricultural Enterprises in the Post-Soviet Countries of Eastern Europe

\begin{tabular}{|c|c|c|}
\hline Group and impact factor & Impact description & Impact assessment \\
\hline \multicolumn{3}{|c|}{ External } \\
\hline Weather conditions & $\begin{array}{l}\text { Despite changes due to global warming processes, they have a mostly } \\
\text { positive impact }\end{array}$ & 4 \\
\hline Institutional environment & $\begin{array}{l}\text { It is undergoing a constant transformation in the context of a large } \\
\text { number of "institutional traps" }\end{array}$ & -5 \\
\hline Corruption & $\begin{array}{l}\text { Consistently high level, which reduces the competitive position of } \\
\text { agricultural producers }\end{array}$ & -6 \\
\hline "Shadow economy" & $\begin{array}{l}\text { Consistently high level, which negatively affects, first and foremost, small } \\
\text { and medium-sized farms }\end{array}$ & -6 \\
\hline Competition in markets & $\begin{array}{l}\text { Sufficient, with the possibility of increasing the share in the relevant } \\
\text { markets with the proper management of its own competitiveness }\end{array}$ & 1 \\
\hline Protectionism & $\begin{array}{l}\text { It is present in one form or another in most markets, especially as } \\
\text { regards the access of agricultural producers from developing countries to } \\
\text { high-margin agricultural markets of developed countries }\end{array}$ & -3 \\
\hline \multicolumn{3}{|c|}{ Production } \\
\hline $\begin{array}{l}\text { Quality and quantity of land } \\
\text { resources }\end{array}$ & $\begin{array}{c}\text { Significant, with a gradual decline in quality due to the problems of doing } \\
\text { business }\end{array}$ & 5 \\
\hline Quality and sufficiency of equipment & Insufficient, especially in small and medium-sized farms & -3 \\
\hline Personnel & $\begin{array}{l}\text { Certain problems with recruitment and training due to the low reputation } \\
\text { of most agricultural producers, as well as migration and emigration } \\
\text { processes }\end{array}$ & -2 \\
\hline $\begin{array}{l}\text { Access to investment and credit } \\
\text { resources }\end{array}$ & Critically restricted, especially in small and medium-sized farms & -6 \\
\hline \multicolumn{3}{|c|}{ Non-material } \\
\hline $\begin{array}{c}\text { Access to leading technologies, } \\
\text { including IT }\end{array}$ & Critically restricted, especially in small and medium-sized farms & -5 \\
\hline Innovation & Insufficient due to lack of funding & -4 \\
\hline Reputation & Critically negative in most agricultural producers & -8 \\
\hline
\end{tabular}

Source: developed by the author.

enterprises in the post-Soviet countries of Eastern Europe and to evaluate their impact on the competitive positions of these enterprises using an appropriate methodology, which will help localize the issues of ensuring (managing) the competitiveness of these entities (Table 4).

In the framework of the assessment of the factors of influence on the competitiveness (competitiveness management) of Eastern European agricultural producers from the post-Soviet countries, we consider it appropriate to divide these factors into three groups:

- external (weather conditions; institutional environment; corruption; "shadow economy"; competition in markets; protectionism);
- production (quality and quantity of land resources; quality and sufficiency of equipment; personnel; access to investment and credit resources);

- non-material (access to leading technologies, including IT; innovation; reputation).

The assessment will be made using the following scale: -10 to -7 (critical negative impact); -6 to -3 (negative impact); -2 to 2 (neutral impact); 3 to 6 (positive impact); 7 to 10 (maximum positive impact).

According to the results of the assessment (see Table 4), we note significant problems of the Eastern European agricultural producers from the post-Soviet 
countries with ensuring their competitiveness and managing it, where one of their main problem is their reputation.

\subsection{Reputation Risk as a Key Element in Ensuring and Improving the Competitiveness Management of Agricultural Enterprises from Post-Soviet Countries of Eastern Europe}

Reputation and reputation risks are becoming increasingly important for business entities, which are reflected in scientific research of the relevant institutions. However, according to Reputation Institute surveys conducted in the UK, there is a clear correlation between reputation of the company and consumption of its products, the higher the reputation of the company, the higher the desire of consumers to buy its products: for companies with high reputation, $83 \%$ of customers are ready to buy it again, while this share was only $9 \%$ and for companies with low reputation (Airmic, 2015).

We note a close relationship between reputation and reputation risk with enterprise competitiveness, while agreeing with Pagach and Warr (2009) that firms with high reputation have greater competitive advantages.

We consider it appropriate, given considerable scientific debate on the role of reputation and reputation risks in the financial and economic activities of enterprises and their impact on the competitiveness of business entities (Ching, 2015; Giorgino and Monda, 2014; Heidinger and Gatzert, 2017; Pérez-Cornejo, Quevedo-Puente and Delgado-García, 2019) to define the terms "reputation" and "reputation risk", as well as to reveal the relationship of reputation with competitiveness and other components of companies' operation (Figure 1).

Reputation will be understood as the component of intangible assets of a business entity, which is determined in the framework of its interaction with its own counterparties and has a direct impact on its value, the amount of profit generated within the financial and economic activity and competitiveness. Reputation risk is the likelihood of an adverse event that could lead to a deterioration in the company's reputation of the company (organization) among its counterparties.

Considering the above mentioned in Figure 1, we note that reputation is the basis of competitiveness of a business entity, while a high likelihood of occurrence of reputation risk or its realization significantly reduce the company's competitive position.

The abovementioned regarding the reputation and reputation risk, as well as their competitiveness, can be fully attributed to agricultural producers, the reasons being:

- $\quad$ within the high similarity of products, consumers choose them by features other than trademarks where reputation is key;

- resource suppliers are more sensitive to cooperation with agricultural producers, where reputation is the basis of such cooperation;

at the beginning of cooperation state institutions and local authorities, especially with foreign

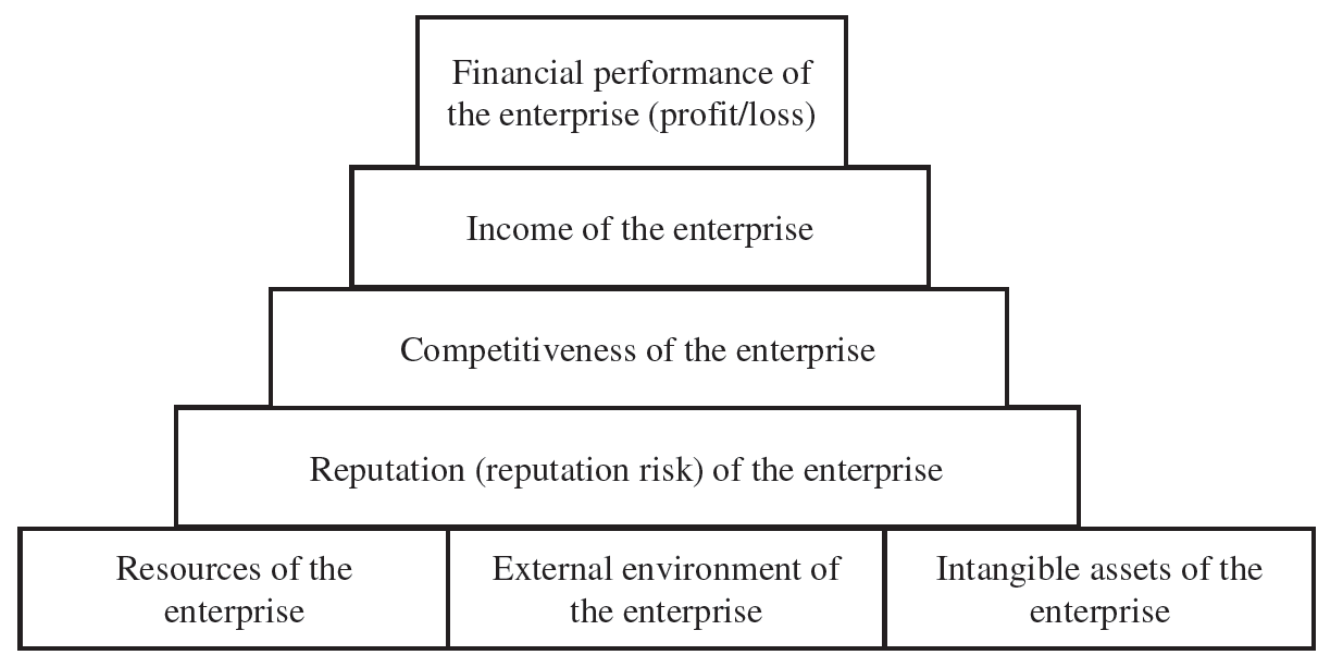

Figure 1: Pyramid of financial and economic activity of the enterprise. 
Table 5: Assessment of the Impact of Reputation (Reputation Risks) on the Relations of Agricultural Enterprises from the Post-Soviet Countries of Eastern Europe with the Main Groups of their Counterparties

\begin{tabular}{|c|c|c|c|}
\hline $\begin{array}{l}\text { Group of } \\
\text { counterparties }\end{array}$ & Reputation risk & Additional costs & $\begin{array}{l}\text { Impact on } \\
\text { competitiveness }\end{array}$ \\
\hline Consumers & $\begin{array}{l}\text { Ongoing efforts to use "information asymmetry" to } \\
\text { their own advantage }\end{array}$ & Countering low loyalty & Negative \\
\hline Suppliers & The crisis of mistrust & $\begin{array}{l}\text { Contractual relations based on } \\
\text { advance payments }\end{array}$ & Negative \\
\hline $\begin{array}{l}\text { State and local } \\
\text { authorities }\end{array}$ & High share of shadow market & Corruption payments & Negative \\
\hline Competitors & Use of raider capture, among other things & Excessive security costs & Negative \\
\hline Investors & $\begin{array}{c}\text { Violation of the rights of not large and foreign } \\
\text { investors }\end{array}$ & $\begin{array}{l}\text { Investment scarcity and their } \\
\text { high cost }\end{array}$ & Negative \\
\hline Rural community & $\begin{array}{l}\text { Violation of the rights of rural community and } \\
\text { unwillingness to implement social projects }\end{array}$ & $\begin{array}{l}\text { Corruption payments and their } \\
\text { counteraction }\end{array}$ & Negative \\
\hline The media & $\begin{array}{l}\text { Ongoing efforts to provide "asymmetric } \\
\text { information" and use manipulation of public } \\
\text { opinion }\end{array}$ & $\begin{array}{l}\text { Costs for financing make-to- } \\
\text { order materials }\end{array}$ & Negative \\
\hline
\end{tabular}

Source: developed by the author.

agro-industrial enterprises, pay special attention to their reputation;

- $\quad$ rural communities choose agricultural producers to operate in their territory, based on the reputation of such companies.

We note that reputation and reputation risks are especially important for agribusinesses from the postSoviet countries of Eastern Europe, as in the early 1990 's and early $21^{\text {st }}$ centuries they often changed their reputation for money (additional profits), which has led to a reputation crisis in the current relationship between such entities and their counterparties, thus reducing their competitive position and leading to additional cash outlay or reduced revenues. In this context, it is important to assess the impact of reputation on the relationship of agricultural producers with the main groups of their counterparties in the context of their competitiveness and additional costs (Table 5).

Thus, we note the high reputation risks, low reputations and, consequently, the problems with competitiveness and its management in the majority of agricultural enterprises from the post-Soviet countries of Eastern Europe, which requires the implementation of appropriate management algorithms.

\subsection{Reputation Risk Management as a Component of Ensuring and Improving the Efficiency of Managing the Competitiveness of Eastern European Agricultural Enterprises}

The extent of the impact of reputation risks on the financial and economic performance of companies and their competitiveness in modern conditions require the implementation of appropriate management (Airmic, 2015). In doing so, reputation risk management will be understood as a set of measures undertaken within a certain algorithm, aimed at reducing the additional costs and losses associated with the deterioration of reputation, as well as preventing its reduction and stimulating the enhancement of the reputation of a business activity. We note that the above fully applies to agricultural producers, including from the post-Soviet countries of Eastern Europe.

Thus, it is necessary to present and describe an algorithm for managing reputation risks that is proposed for use in Eastern European agro-industrial enterprises operating in the territory of the countries that were part of the Soviet Union (Figure 2).

We note that the key elements of the proposed algorithm (see Figure 2) are understanding the importance and priority of reputation risk by owners and management of agricultural producers, determining its components, as well as evaluation.

Without understanding priority of reputation risks and managing them by the owners and management, the implementation of management measures is inappropriate. We note that according to the Reputation Institute, in 2015, only one-third of the companies surveyed confirmed reputation risk management (Airmic, 2015). The situation for agricultural producers from the post-Soviet countries of Eastern Europe is complicated by the reluctance of their owners and managers to recognize reputation risks as a priority for competitiveness and management. 


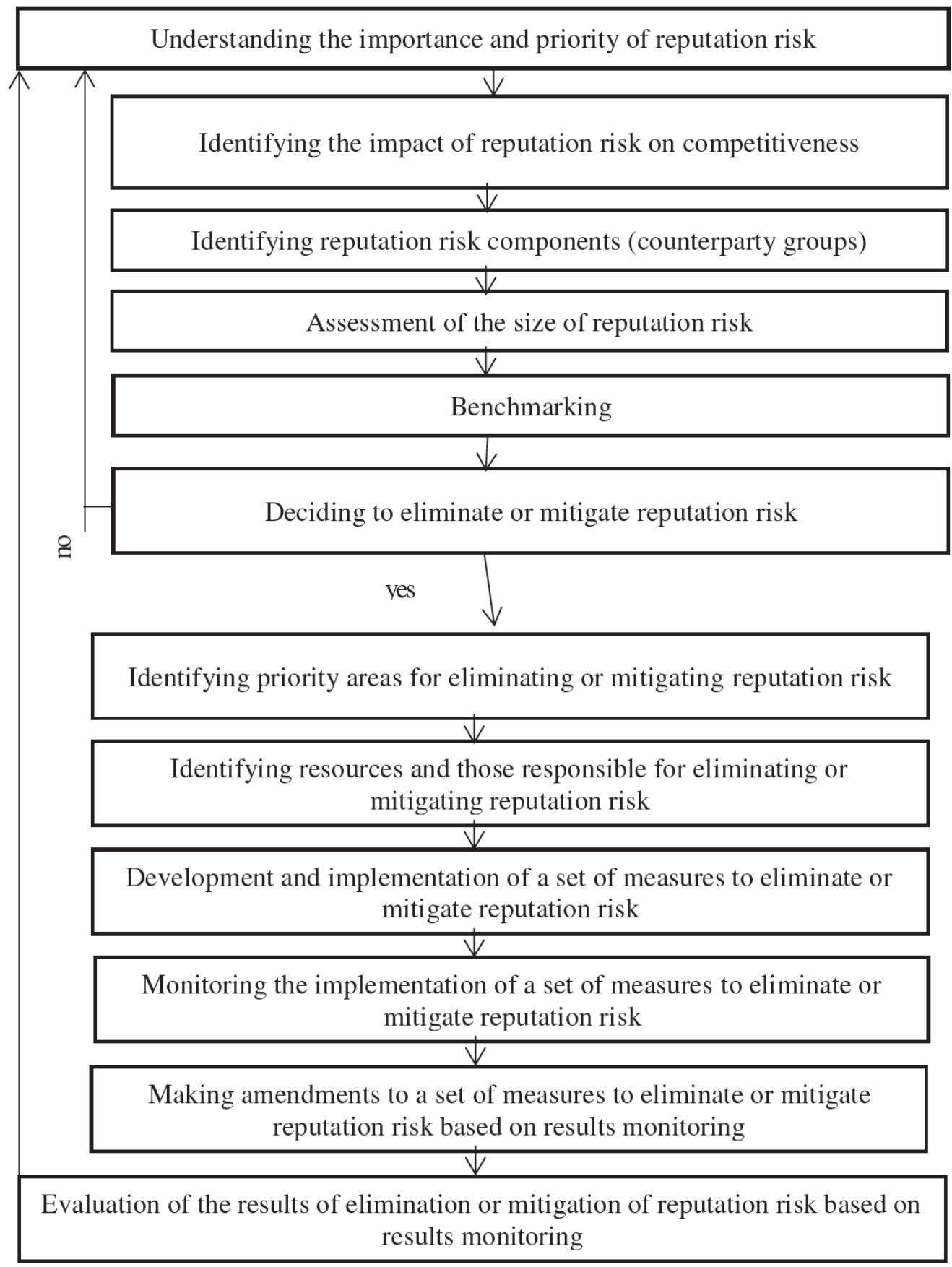

Figure 2: Reputation risk management algorithm for agricultural enterprises from post-Soviet countries of Eastern Europe. Developed by author based on: Pagach and Warr (2009), Giorgino and Monda (2014), Airmic (2015).

Regarding the components of reputation risk, we consider it appropriate to associate them with identified groups of counterparties (see Table 5). The interaction of an agricultural enterprise with each of the groups of counterparties carries a reputation risk component.

A key element of the proposed algorithm is evaluation of the size of the reputation risk. For its evaluation it is proposed to use the integral indicator of reputation risk (Irr), which will include the reputation risks for each of the main groups of counterparties (see Table 5):

Irr = RRc + RRs + RRsla + RRc + RRi + RRrc + RRm, (1) where Irr - the integral indicator of reputation risk (values from 70 to - 70); RRc - reputation risk of consumer relations (values from 10 to -10); RRs reputation risk of supplier relations (values from 10 to 10); RRsla - reputation risk of relations with state and 
Table 6: Criteria for Reputation Risk Evaluation for Agricultural Enterprises in the Eastern European Countries

\begin{tabular}{|c|c|c|c|c|c|}
\hline Evaluation scale & $-70<\mid r r<-49$ & $-48<\mid r r<-21$ & $-20<\mid r r<14$ & $15<\mid r r<-47$ & $48<\mid r r<70$ \\
\hline Reputation risk level & $\begin{array}{l}\text { Critically high } \\
\text { reputation risk }\end{array}$ & High reputation risk & $\begin{array}{l}\text { Average reputation } \\
\text { risk }\end{array}$ & $\begin{array}{l}\text { Low reputation } \\
\text { risk }\end{array}$ & $\begin{array}{l}\text { The lowest possible } \\
\text { reputation risk }\end{array}$ \\
\hline
\end{tabular}

Source: developed by the author.

local authorities (values from 10 to -10); RRc reputation risk of competitor relations (values from 10 to -10); RRi - reputation risk of investor relations (values from 10 to -10); RRrc - reputation risk of rural community relations (values from 10 to -10 ); RRm reputation risk of media relations (values from 10 to 10).

At the same time, it is proposed to determine the reputation risk of the relations between the agricultural producer and the main groups of counterparties using the following scale: -10 to -7 (critically high reputation risk); -6 to -3 (high reputation risk); -2 to 2 (average reputation risk); 3 to 6 (low reputation risk); 7 to 10 (the lowest possible reputation risk). Given the above, it is possible to form criteria for the assessment of reputation risk for the agricultural producer according to the integral indicator (Table 6).

We note that the above method of evaluation, in addition to direct evaluation of the size of the reputation risk for the agricultural producer will identify the problem groups of contractors, reputation with which should be paid special attention in the framework of ensuring, maintaining or enhancing competitiveness, as well as improving efficiency of its management.

Thus, agricultural enterprises from the post-Soviet countries of Eastern Europe require the introduction of reputation risk management, which should be based on an appropriate evaluation of these risks using the developed methodology, which, in turn, will allow obtaining a significant tool for influencing their competitiveness at local, regional, national, international, global product markets.

\section{DISCUSSION}

Agricultural production in most post-Soviet countries of Eastern Europe (with the exception of Lithuania, Latvia, Estonia) is increasingly important for the sustainable development of these countries (FAO, 2018; Kimhi and Lerman, 2015; Röthig, 2017). At the same time, the problems of ensuring and managing the competitiveness of Eastern European agricultural producers from the countries of the Soviet Union require them to find new ways of solving these problems, where the key is improving reputation and combating reputation risks that were formed during the operation of the economic entities in the markets. This situation requires the development and implementation of appropriate management. In doing so, it is important to test the relevant hypotheses.

The hypothesis that the agricultural sector of the economy plays an increasing role in the economic systems of the post-Soviet countries of Eastern Europe, acting as a basis for their sustainable development, has been partially confirmed. Thus, the new member states of the European Union (Lithuania, Latvia, Estonia) have significantly reduced the share of agricultural production in their economies, building their development on the basis of a post-industrial model. It is also possible to identify a group of countries where the basis of the economy is the production and sale of energy resources (Azerbaijan, Kazakhstan, Russia), where the agricultural sector is important but not a priority for the development of the national economy. However, the hypothesis has been confirmed for all other post-Soviet countries of Eastern Europe (Belarus, Armenia, Georgia, Moldova, Ukraine).

At the same time, the study of the competitiveness of agricultural producers from the post-Soviet space of Eastern Europe, as well as the level of management of their competitive positions in national, international and world markets showed a significant number of problems to be solved.

The evaluation of the competitiveness of agricultural enterprises from the post-Soviet countries of Eastern Europe and management of the competitiveness of these entities has allowed to identify reputation risk as one of the key negative factors of influence, where the problem is the formation of reputation in relations with all major groups of counterparties.

It has been proved that the formation of an effective reputation risk management algorithm based on an appropriate evaluation methodology is a key element in ensuring competitiveness and a basis for improving its management efficiency in Eastern European agricultural producers from the post-Soviet countries. 
In view of the above, it can be noted that the objective of the study, which was set at the beginning of the work, was achieved. A key value of this research paper is the developed algorithm of reputation risk management for agricultural enterprises from the postSoviet countries of Eastern Europe, which includes the author's method of evaluating the reputation risks of agribusinesses. In this regard, some limitations can be identified in the application of the results of this research paper, namely: the need to review the proposed methodology for evaluating reputation risks with possibility of adjustments; the difficulty of using only expert judgment within the evaluation of the components of the integral reputation risk indicator. At the same time, the stated restrictions do not diminish the scientific and practical value of this research paper and outline the prospects of further scientific research.

\section{CONCLUSION}

Reputation risks have become one of the key problems in managing the competitiveness of agricultural enterprises in the post-Soviet countries of Eastern Europe. Having acquired critical importance in the current conditions of functioning and development of the agricultural sector of Eastern European countries from the post-Soviet economic space, reputation risks require the development and implementation of appropriate management.

The developed algorithm of reputation risk management will allow, on the one hand, reducing or counterbalancing their impact on the competitiveness of agricultural producers from the post-Soviet countries of Eastern Europe, and, on the other hand, will become a key component of improving the competitiveness management of these entities.

The practical implementation of the proposals and conclusions of this research paper should be considered in the context of their importance for enhancing the reputation and competitiveness of agricultural enterprises and the agricultural sector of the economies of the post-Soviet countries of Eastern Europe.

Prospects for further research based on and using the scientific results of the conducted research are as follows: detailing the place of the reputation risk management in managing competitiveness of agricultural enterprises from post-Soviet countries of Eastern Europe; detailing components of the methodology of reputation risk assessment for Eastern European producers of agricultural products from the
post-Soviet economic space. At the same time, partly the results of this study can be used after their modification to assess and manage the reputation risk of agricultural companies from other groups of countries in which the agricultural sector plays a significant role, serving as the basis for sustainable development of countries. For this, it is initially necessary to structure the key producers and groups of counterparties of these producers, which may be specific to these countries. Based on this, we can apply the risk assessment methodology proposed in the work and use the reputation risk management algorithm to increase the competitiveness of agricultural producers of these groups of countries.

\section{REFERENCES}

Airmic. 2015. Defning and Managing Reputation Risk. A Framework for Risk Managers. Guide 2015. London: Reputation Institute.

AON. 2019. The Global Top 10 Risks. Retrieved June 6, 2019 (https://www.aon.com/2019-top-global-risks-managementeconomics-geopolitics-brand-damage-insights/index.html)

Bečvářová, Věra. 2008. Issues of Competitiveness of the Present Agriculture. Agricultural Economics-Czech, 54(9): 399-405. https://doi.org/10.17221/2698-AGRICECON

Chang, Chia-Lin and Michael McAleer. 2014. How Should Journal Quality be Ranked? An Application to Agricultural, Energy, Environmental and Resource Economic. Journal of Reviews on Global Economics 3: 33-47.

https://doi.org/10.6000/1929-7092.2014.03.05

Ching, Ward. 2015. Defining Reputational Risk. Risk Management Monitor. Retrieved June 6, 2019 (https://www.riskmanagementmonitor.com/defining-reputational-risk)

Chryniewicz, Łukasz, Dmytro Kyryliuk, and Michał Wojtaszek. 2016. "Key Factors Increasing Competitiveness of Agriculture in Ukraine." Roczniki Naukowe Stowarzyszenia Ekonomistów Rolnictwa i Agrobiznesu 1(18): 35-42.

Csaki, Csaba, and Antonio Nucifora. 2006. Ten Years Of Transition In The Agricultural Sector: Analysis and Lessons from Eastern Europe and the Former Soviet Union Retrieved June 6, 2019 (https://services.bepress.com/cgi/viewcontent.cgi? article $=1005 \&$ context $=$ sjohnson)

Czyżewski, Andrzej and Katarzyna Smędzik-Ambroży. 2015. "The Efficiency of Agricultural Sector in Poland in Light of OutputInput Model." Management 1(1): 113-125. https://doi.org/10.1515/manment-2015-0009

Eccles, Robert G., Scott C. Newquist and Roland Schatz. 2007. "Reputation and Its Risks." Harvard Business Review Retrieved June 10, 2019 (https://hbr.org/2007/02/reputationand-its-risks)

Esterhuizen, Dirk. 2006. An Evaluation of the Competitiveness of the South African Agribusiness Sector. Pretoria: University of Pretoria.

FAO. 2018. Review of Agricultural Trade Policies in the post-Soviet countries 2016-17 Retrieved June 10, 2019 (http://www.fao. org/policy-support/resources/resources-details/en/c/1152540)

FAO. 2019. World Food and Agriculture. FAO Statistical Yearbook. Rome: Food and Agriculture Organization of the United Nations.

Giorgino, Marko and Barbara Monda. 2014. An integrated framework for reputational risk assessment: modelling reputational risk as an indirect effect. Retrieved June 8, 2019 (https://www. politesi.polimi.it/bitstream/10589/107897/3/2015_04_Professi one.pdf) 
Gunjal, Kisan. 2016. Agricultural Risk Management Tools. Retrieved June 8, 2019 (http://p4arm.org/app/uploads/2016/05/PARM_ ARM-Tools-Elearning_Gunjal_May2016.pdf)

Gusakov, Vladimir G. and Alexander P. Shpak. 2018. "High-Priority Guidelines for Raising Efficiency, Competitiveness and Stability Of Agrarian Sector Development in the Republic of Belarus." Proceedings of the National Academy of Sciences of Belarus. Agrarian Series 4(56): 401-409. https://doi.org/10.29235/1817-7204-2018-56-4-401-409

Heidinger, Dinah and Nadine Gatzert. 2017. Awareness, Determinants, and Value of Reputation Risk Management: Empirical Evidence from the Banking and Insurance Industry. Working Paper. Department of Insurance Economics and Risk Management Friedrich-Alexander University ErlangenNürnberg (FAU). https://doi.org/10.1016/j.jbankfin.2018.04.004

Hvid, Anna K. 2013. Fighting for Rents: Agricultural Windfall Gains and Social Change in Land-Abundant Developing Countries. Journal of Reviews on Global Economics 2: 375-389. https://doi.org/10.6000/1929-7092.2013.02.26

Ilina, Elena L., Konstantin A. Miloradov and Andrey P. Kovaltchuk. 2019. "Green Hotel": Concepts And Implementation. Journal Of Environmental Management and Tourism 10(2): 300-306.

Khasanov, Rinat and Mikhail Xenophon. 2018. Agricultural Market Overview. Moscow: Deloitte Research Center in the CIS.

Kimhi, Ayal and Zvi Lerman. 2015. Agricultural Transition in PostSoviet Europe and Central Asia after 25 Years. Israel, Rehovot: IAMO.

KNOEMA. (2019). Statistical Data. Retrieved June 8, 2019 (https://knoema.ru/atlas)

Kovaltchuk, Andrey P, Ekaterina A. Blinova and Konstantin A. Miloradov. 2017. Increasing the competitiveness of the russian hotel enterprises under modern conditions. Journal of Environmental Management and Tourism 8(2): 407-416.

Kovaltchuk, Andrey P., Elena A. Dedusenko, Ekaterina A. Blinova, Konstantin A. Miloradov. 2016. Concept and procedures of crisis management in Russian hotel enterprises. Journal of Environmental Management and Tourism 7(3): 473-480.

Kuipers, Abele, Andriy Rozstalnyy and Gerry Keane, eds. 2014. Cattle Husbandry in Eastern Europe and China: Structure, Development Paths and Optimization. Wageningen: Wageningen Academic Pub. https://doi.org/10.3920/978-90-8686-785-1

Maslova, Vlada, Natalya Zaruk, Clemens Fuchs and Mikhail Avdeev. 2019. "Competitiveness of Agricultural Products in the Eurasian Economic Union." Agriculture 3(9): 61-74. https://doi.org/10.3390/agriculture9030061
Matyja, Małgorzata. 2016. "Resources Based Factors of Competitiveness of Agricultural Enterprises." Management 20(1): 368-381. https://doi.org/10.1515/manment-2015-0045

Pagach, Donald and Richard Warr. (2009).Corporate Reputational Risk and Enterprise Risk Management: An Analysis from the Perspectives of Various Stakeholders Retrieved June 8, 2019 (https://pdfs.semanticscholar.org/7f91/f34e0c3a0b7a8f 6ae7b93a1e8471d0745601.pdf)

Patyka, Nataliia. 2018. "Priorities Ensuring of the Ukraine's Agriculture Competitiveness in the World Markets." Agricultural and Resource Economics: International Scientific E-Journal 4(4): 130-145.

Pérez-Cornejo, Clara, Esther de Quevedo-Puente and Juan Bautista Delgado-García, 2019. "How to Manage Corporate Reputation? The Effect of Enterprise Risk Management Systems and Audit Committees on Corporate Reputation." European Management Journal 37(4): 505-515. https://doi.org/10.1016/j.emj.2019.01.005

Petrick, Martin and Peter Weingarten. 2004. The Role of Agriculture in Central and Eastern European Rural Development:Engine of Change or Social Buffer? Israel, Rehovot: IAMO.

Röthig, Marcel, ed. 2017. Reindustrialise Eastern Europe? Perspectives of Progressive Economic Policy in The Countries of the Eastern Partnership, Russia and Germany. Kyiv: Friedrich-Ebert-Stiftung (FES), Regional Offce "Dialogue Eastern Europe".

Sachitra, Vilani and Siong-Choy Chong. 2016. "Firm Level Competitive Advantage in the Agricultural Sector: A Research Agenda." British Journal of Economics, Management \& Trade 12(3): 1-12. https://doi.org/10.9734/BJEMT/2016/24152

Shvets, Yulia O. and Anna A. Butenko. 2017. "Analysis of Competitiveness of Agricultural Enterprises: Main Problems and Prospects." The Journal of Zhytomyr State Technological University. Series: Economics, Management and Administration 2(80): 49-53. https://doi.org/10.26642/jen-2017-2(80)-49-53

Trubilin, Alexandr, Vladimir Sidorenko and Pavel Mikhailushkin. 2016. "Competitiveness of the Agricultural Sector of Russia." International Agricultural Journal 5: 4-8.

USDA. 2019. Risk in Agriculture. United States Department of Agriculture Economic Research Service. Retrieved June 11, 2019 (https://www.ers.usda.gov/topics/farm-practicesmanagement/risk-management/risk-in-agriculture

\section{DOI: https://doi.org/10.6000/1929-7092.2019.08.74}

(c) 2019 Zakharchenko et al.; Licensee Lifescience Global.

This is an open access article licensed under the terms of the Creative Commons Attribution Non-Commercial License (http://creativecommons.org/licenses/by-nc/3.0/) which permits unrestricted, non-commercial use, distribution and reproduction in any medium, provided the work is properly cited. 